Rules should be framed to deal with general rather than particular problems in order to ensure that they remain valid for many years in the rapid and continuous technological change occurring in cross-border trade in services.

8. Given the characteristics of the services sector, protectionism here impedes both trade and investment. The debate about the status and rights of foreign subsidiaries is a handicap for an early and successful conclusion to the negotiations. In this situation the procedure might be eased by beginning with trade questions and turning to investment issues at a later date.

9. The attitudes of the majority of developing countries, which range from scepticism to rejection, could be countered by measures that would improve their export prospects. This would also ease their debt problems. The higher the industrial countries' demands regarding services, the wider they must open their markets to traditional and manufactured products from the Third World.

10. The successes and failures of the GATT have mirrored the predominant trends in the trade policies of the leading world trading countries and they continue to do so. However, there is also need for institutional reform that provides for effective monitoring of rules and creates sanction mechanisms to ensure that contracting parties abide by their existing and new commitments. Nonetheless, it would be a mistake to develop the GATT into a kind of international court; political consensus is its life blood.

\title{
Developing Countries and Services in the Uruguay Round
}

\author{
by Ad Koekkoek, Rotterdam
}

nternational trade in services has been a focus of interest for some time. It first came into prominence in the run-up to the GATT Ministerial Conference in 1982; since then there has been continued discussion, within GATT and elsewhere, on its many aspects. The background to this discussion is the desire of many industrialized countries to subject trade in services to a regime similar to that governing trade in goods, with a view to minimizing unfair practices.

There are many reasons for such an approach. Trade in services offers the industrialized countries scope for adjusting their economies, bearing in mind that it is precisely in the field of modern services that they enjoy comparative advantages. Modern services after all are

* Erasmus University Rotterdam and Ministry of Foreign Affairs, the Netherlands, Directorate General for Development Co-operation. The article expresses the author's personal opinions. relatively human and physical capital-intensive. In addition liberalization of trade in services could serve as a self-sustaining generator of growth, as did liberalization of trade in goods in the fifties and sixties.

In contrast to this emphasis on international trade aspects, developing countries assigned key significance to the role of the service sector in the development process. The special position and role of services in the development process was emphasized in order to signify that dealing with services on GATT lines was not as such the right approach, that GATT was not the proper forum and that dealing with services in that context would only produce disadvantages for developing countries.

This was the framework within which the debate on services was conducted in the period 1982-86, during the preparations for a new GATT round. The discussions 
finally led to the setting up of a negotiating group for services in Part II of the Uruguay Declaration. It should be pointed out here that this Part was not issued by the Ministers as GATT contracting parties, but was produced by them in an ad hoc meeting. On the other hand the Group on Negotiations on Services, like the negotiating group established for goods, reports to an umbrella body, the Trade Negotiations Committee.

The text of Part II of the Declaration makes it clear that the aim of the negotiations is to establish a multilateral framework of principles and rules for international trade in services, with a view to increasing that trade and as a means of promoting the economic growth of all the trading partners and the development of the developing countries.

This article will now examine the special interests of developing countries within the framework of these negotiations against the background of the stated objective. It is of course not possible to go into extensive detail. Where it is found necessary or worthwhile reference will therefore be made to relevant literature.

\section{Definition of Services}

There is no absolute and comprehensive definition of "services". Two statistical classifications may however serve as a basis for delimiting the concept. The first is the national accounts classification under which the broadest definition of services includes constructions, public utilities, commercial and financial services, transport and communications, government activities and other services. The narrowest definition excludes the construction, public utility and government sectors. ${ }^{1}$ From the point of view of international trade, without wishing to make any further breakdown of the sectors in question, the broad definition, minus government and public utilities, is presumably the most relevant one.

A second statistical classification, which is much cruder than that presented above, is applied for the balance of payments. Payments for deliveries of goods and services and income flows are recorded in the balance of payments current account. ${ }^{2}$ In the broader view services would include transport, travel, other services and income flows (including factor services). In a narrower view income flows would not be included here.

\footnotetext{
1 UNCTAD Production and Trade in Services Policies and their Underlying Factors bearing upon International Service Transactions, document TD/B/941/rev.1, Geneva 1985, p. $11 \mathrm{ff}$.

2 IMF. Balance of Payments Manual: Fourth Edition, Washington, D.C., 1977, p. 66.
}

The remarks below are based on the national accounts definition. The balance of payments definition is relevant to figures relating to international trade in services. Indeed that is the only way trade figures for services are systematically collected. ${ }^{3}$

\section{Characteristics}

The first aspect to note in connection with services is that they are in many cases intangible or of an nonmaterial nature (insurance, for example). This applies to a lesser extent when a physical product is the carrier of the service, e.g. a gramophone record or a computer tape. A second aspect is that it is not usually possible to lay up stocks of services or to transport them. Hence they must often be produced at the place of consumption or consumed at the place of production. Services are also less standardized, less uniform than goods. For this reason it is also more difficult to assess their value in commercial traffic.

From the fact that services usually cannot be produced for stock and are not transportable it follows that trade in services, more than trade in goods, goes hand in hand with foreign investment.

However, the fact that services are not transportable, although transport itself is a service, does not mean that they cannot be provided at a distant location. In this context reference is often made to "over-the-wire services" using modern communications technology. ${ }^{4}$ In general it may be added here that the development of international trade in services is heavily influenced by technological developments.

Because of the non-material nature of services it is more difficult to determine when they are being imported, or imports are more difficult to record. At the same time, therefore, tariffs are not a viable instrument for the protection of domestic production of services. In other words protective measures fall more into the category of non-tariff barriers, e.g. public procurement policy, taxation, subsidies and regulatory activity in general. Protection may also, more than in the case of goods, take the form of measures to block the investment necessary for trade in services, e.g. through establishment requirements. ${ }^{5}$

\footnotetext{
${ }^{3}$ For further comments regardıng the distinction between trade in services, production factor flows and payments, see below.

4 See J. N. B h a g w a ti : Splınterıng and Disembodiment of Services and Developing Nations, in: The World Economy, June 1984, pp. 133143.

5 See, for example, UNCTAD Production and Trade in Services ..., op. cit., for a fuller discussion of the conceptual aspects of services.
} 


\section{Importance to Developing Countries}

There are two ways of assessing the quantitative importance of the service sector to developing countries, viz. through the contribution of services to national income and employment and through the importance of services in trade. Depending on the definition used, services accounted for between 37 and $51 \%$ of national income in developing countries in 1980 . Services in the broadest sense accounted for around $43 \%$ of employment for a sample of fourteen developing countries. Also in 1980 developing countries had a share in world trade in non-factor services of around $18 \%$. This corresponded with some $12 \%$ of their total exports of goods and services. ${ }^{6}$ In the seventies, developing countries were net importers of services, although the deficit was mostly accounted for by the oil exporters. Moreover, there were also a number of net exporters. ${ }^{7}$ These global figures indicate that services form a sector of not inconsiderable importance to developing countries, both in terms of their own production and in terms of international trade.

6 The source for these, and more, figures is UNCTAD: Production and Trade in Services ..., op. cit., pp. 12, 17,21.
Figures of this kind do not, of course, say a great deal about the qualitative role of services in the development process. $^{8}$ This is only of relevance to the present issue insofar as the role of services in the development process differs substantially from that of goods and has different consequences with regard to the development and trade policy to be pursued. Two remarks may suffice here. To begin with, services, particularly modern services, are closely bound up with high technology. Thus aspects relating to technology transfer and the role of technological progress in development are of relevance. Secondly, trade in services, more than that in goods, goes hand in hand with direct foreign investment. This aspect will be dealt with more fully below.

\section{Desirability of Liberalization}

Liberalization of trade in services is desirable on the same grounds as liberalization of trade in goods. The

\footnotetext{
7 Figures in this respect can be found in UNCTAD: Services and the Development Process, document TD/B/1008/rev.1, Geneva 1985, p. $35 \mathrm{ff}$.

8 For a more detailed discussion of this aspect see UNCTAD: Services and the Development Process: further studies, document TD/B/1100, Geneva 1986, Ch. III.
}

\section{PUBLICATIONS OF THE HWWA-INSTITUT FÜR WIRTSCHAFTSFORSCHUNG-HAMBURG}

Eckhardt Wohlers/Günter Weinert

\section{UNTERSCHIEDE IN DER BESCHÄFTIGUNGSENTWICKLUNG ZWISCHEN DEN USA, JAPAN UND DER EG}

Vergleichende Untersuchung der Gründe für die unterschiedliche Beschäftigungsentwicklung in den USA, Japan und der EG seit 1973

\section{(DIFFERENCES IN EMPLOYMENTTRENDS IN THE USA, JAPAN} AND THE EC)

(A Comparative Study of the Reasons for the Differences in Employment Trends in the USA, Japan and the EC since 1973)

This study was conducted in 1985 for the Federal Ministry of Economics. It describes the differences in employment trends in the USA, Japan and the EC in the period 1973 to 1983 and examines the reasons for these differences. The empirical analysis concentrates on differences between the individual countries in growth rates, in the structure of growth processes, in trends in real wage levels and wage patterns, in the flexibility of labour markets and in basic political concepts as possible reasons for the differences in employment trends. (In German)

Large octavo, 295 pages, 1986, price paperbound DM 48,-

ISBN 3878953070
V E R L A G
W E
T A R C H I V
G M B H
H A M B U G 
theoretical basis is that liberalization of trade promotes the economic welfare of all those involved in trade. It should be emphasized however that this refers to liberalization of trade and not of the movement of production factors or income flows. On the contrary, the immobility of production factors, for example, is one of the basic premises of the underlying theoretical model. With regard to trade in services, of course, there is a problem since in this case, more than in that of goods, a certain degree of mobility of production factors (labour, capital) is necessary. We shall return to the implications of this later. Suffice it to state here that the liberalization of movements of production factors has many noneconomic implications; this is true of both capital (sovereignty considerations) and labour (migration).

It is of course not the intention here to go into all the theoretical aspects. Suffice it to note in passing that the main exception to the rule that liberalization is conducive to economic welfare stems from the fact that some countries are large enough to influence the world market price by their trade policy. Protective measures on their import side then lead to downward pressure on their import prices. In principle this increases the welfare of the importing country. ${ }^{9}$ It can be said in general however that trade liberalization leads to specialization on the basis of comparative advantages and hence to an increase in welfare.

\section{Non-applicability of Traditional Theories}

As far as trade in services is concerned, criticism of the assumed welfare-increasing effect of liberalization consists mainly in the voicing of doubts regarding the applicability to trade in services of traditional theories of comparative advantage..$^{10}$ It is of course clear that, where services differ conceptually from goods, existing trade theories are not immediately applicable to trade in services in all respects. In addition, partly because of the problem of availability of relevant data, it is also very difficult to test the validity of trade theories when applied to trade in services. Nevertheless some attempts have been made which have yielded positive results with regard to the ability of traditional trade theories to explain trade in services." The conclusion here is that, as in the case of goods, the relative availability of

\footnotetext{
9 The theoretical consideration here is that of the optimum tariff.

10 See for example UNCTAD: Services and the Development Process, op. cit., p. 43; and, to a lesser degree, UNCTAD: Services and the Development Process' further studies, op. cit., p. $13 \mathrm{ff}$

"Examples: A. Sapır, E. Lutz: Trade in Services Economic Determinants and Development Related issues, World Bank Staff Workıng Paper No. 480, Washington, D C., 1981; A. S a p I r' Trade in Investment-related Technological Services, in. Worla Development. Vol. 14 , No. 5, 1986, pp. 605-622.
}

production factors in a country, together with the intensity of use of those factors in the production process, determines the trading position of the country. In concrete terms this means that, generally speaking, the developed countries have a comparative advantage in the production of capital- and knowledge-intensive services and that developing countries have a comparative advantage in the production of labourintensive services.

The overall conclusion from these theoretical considerations is that world-wide liberalization of trade in services will lead to more imports rather than to more exports in developing countries and hence to pressure on the current account. The reason for this is that capital- and knowledge-intensive services are more readily tradable than labour-intensive services. It would be incorrect however to conclude that there is nothing to be gained by developing countries on the export side. There are possibilities in the sectors "construction"12 and "printing", there are also possibilities in modern services. Examples may be found that take forms analogous to the contracting arrangements in the textile and garment industries, in other words a labourintensive element in the service production process is contracted out to a developing country. ${ }^{13}$ In a more general way Bhagwati stresses the dynamic aspect of trade in services, where comparative advantages can rapidly arise for developing countries too. ${ }^{14}$ It goes without saying of course that this is more relevant to advanced developing countries that to others. The rapid growth in the export of industrial goods by developing countries since the sixties may serve as an example here. It should be emphasized in addition that gains from trade liberalization for developing countries are of course also to be sought in the counter-concessions which stand to be secured in the field of trade in goods. Hence industrialized countries must also offer scope for this.

\section{The Role of Services in the Development Process}

Apart from doubts as to the applicability of traditional trade theories, the role played by services in the development process constitutes a major argument against liberalization of trade in services. ${ }^{15}$ The emphasis here is laid on the importance of an efficient

12 The problem of labour migration is soon encountered here, however

${ }^{13}$ UNCTAD gives an example of this: in the context of ofíce automation, part of the clerical process is transferred to a developing country, for example the recording of data on computer tapes or word processing. See UNCTAD: Services and the Development Process, further studies, op. cit., p. 15.

14 See J.N. Bhagwati, op. cit.

15 UNCTAD Services and the Development Process, further studies, op. cit., Ch. l., deals more fully with this aspect. 
and well-organized infrastructure and government services sector and of the traditional financial services sector. The importance of modern services, also referred to as business services or producer services, is likewise stressed since they consist mainly of intermediary services. Another aspect of modern services is that to a large extent they go hand in hand with the application of advanced technology. These modern services are increasingly being supplied externally to other enterprises, instead of being produced internally. This specialization process is facilitated inter alia by the fact that industrialists have developed the necessary knowledge in existing firms. A specialization process of this kind constitutes a stimulus to the economy because of increasing competition, the spread of technology and greater access for other, particularly smaller, firms to such services.

UNCTAD ${ }^{16}$ notes that this modern services sector is poorly developed in developing countries and voices the fear that a sudden liberalization of trade in services would lead mainly to an increase in the import of services, instead of acting as a stimulus to developing

16 lbid., p. 8. countries' own service industries. On the other hand it is also pointed out that a certain foreign presence may have a stimulating effect on this sector. Possibilities which come to mind here are technology transfer, demonstration and competition aspects.

In fact therefore the problem is not so much the distinct role which services are assumed to play in the development process as the fear that the local service industry might fail to develop satisfactorily because of foreign competition. Another reason put forward for shielding the domestic service market from the world market derives from the role played by technology in the modern services sector. The advocates of such a policy stress the importance of indigenous technological development, which would benefit from isolation from international influences. This consideration is of course closely bound up with the objective already mentioned of promoting the establishment of a domestic service industry. In this case too the better solution is presumably to seek maximum benefit from foreign technological developments and to integrate them into the domestic production structure. Put another way, why should an inward-looking policy for services be the right one, when there are increasing signs that an export-

\title{
OLLANGEBOTSMODELLE: ENTSCHEIDUNGSHILFEN FÜR DIE WIRTSCHAFTSPOLITIK? (OIL SUPPLY MODELS: DECISION-MAKING AIDS FOR ECONOMIC POLICY?)
}

\begin{abstract}
In the years $1973 / 74$ and again in 1979/81 the world economy was shaken by steep increases in the price of oil. Adjustment to high energy prices became a central task for economic policy both in industrialised countries and in the Third World. This book examines the question, whether and in what way the numerous models designed to explain future oil supply are able to provide the oil-importing western industrialised countries with decision-making aids for the evaluation of the supply situation during the critical phase of the next twenty years. The author lays particular emphasis on optimization models, which are based on the theory of exhaustible resources, and which allow the price and quantity decisions of the oil-suppliers to be derived from the model. (In German)
\end{abstract}

Large octavo, 236 pages, 1986, price paperbound DM 46,-

ISBN $387895302 \mathrm{X}$
V E R L A G
W E L T A R C H I V
G M B H
H A M
B U R G 
oriented strategy overall is better for development? This is all the more valid as it is precisely in the service sector that developing countries are generally at a comparative disadvantage. Modern services are after all, generally speaking, knowledge-intensive.

\section{The Applicability of GATT}

Developing countries do not consider GATT to be the appropriate forum for liberalization of services trade, although they have agreed to negotiate under GATT auspices. In a nutshell, the reasons for their position, apart from a negotiating stance, are the following. ${ }^{17}$ Firstly, they consider GATT only relevant for trade in goods. Even in this respect their experience in GATT, they say, has not been very good. Besides, there are other international institutions which already deal with various service sectors. Secondly, they fear that industrialized countries want direct foreign investment brought under GATT rules. Thirdly, they are afraid that accommodating services under GATT will provide legal scope for intersectoral retaliation, i.e. the taking of punitive measures against their goods exports by industrialized countries when they find their service exports to developing countries being hindered.

Nevertheless, for reasons presented more fully elsewhere, GATT is probably to be preferred both for the negotiations and for the application of its principles. ${ }^{18} \mathrm{We}$ will now discuss how developing countries' legitimate concerns can be taken care of in liberalizing trade in services according to GATT principles. ${ }^{19}$

\section{The Position of Developing Countries}

The considerations set out above regarding the liberalization of trade in services and the special nature of services raise a number of points of particular concern to developing countries. ${ }^{20}$ The starting-point for the discussion which follows is that liberalization of trade in services should as far as possible contribute to the

17 For a more extensive discussion of these and other matters, see L. B. M. Mennes, K. A. Koekkoek: Objectives of and Problems with the Developıng Countries in the New GATT Round, paper prepared for the meeting on the Position of the European Community in the New GATT Round, convened by the Spanısh Ministry of Finance and the Economy and the Trade Policy Research Centre, Madrid, Spain, 2-4 October 1986; Ad Koekkoek, Jeroen de Leeuw: The Applicability of the GATT to the International Trade in Services: General Considerations and the Interest of Developing Countries, in: Außenwirtschaft, Swiss Review of International Economic Relations, Vol. 42, No. 1, 1987, pp. 65-84.

${ }^{18}$ Ad Koekkoek, Jeroen de Leeuw, op. cit.

19 Recently the OECD published a document in which GATT principles are applied and adjusted for application to services; see OECD: Elements of a Conceptual Framework for Trade in Services, Paris 1987. For several reasons scant attention is paid in that document to developing countries' interests. development potential of developing countries. A distinction is made in this discussion between the import side and the export side of a developing country's economy.

\section{The Import Side}

The main problem which the developing countries see in the application of GATT principles to services does not stem from the most favoured nation principle but from that of national treatment. Because of the nature of services, countries can hardly protect their service sectors by border controls; they must resort to internal regulation and financial mechanisms. National treatment requires that domestic regulations should not discriminate according to the origin of a product, in other words should not have the effect of protecting domestic industry. However, the developing countries - and they are not alone in this - feel that there are a number of legitimate grounds for protecting the service sector against foreign competition. To begin with of course there are the usual considerations which are already accepted in the case of goods as grounds for protecting domestic industries. Aspects of national security and the "infant industry" concept come to mind here. ${ }^{21}$ In the case of services considerations specific to individual sectors are often added to these, such as the preservation of cultural identity, consumer interests, public health, monetary policy etc. ${ }^{22}$

Obviously there are a number of legitimate grounds for protection - for example the requirements of public health with regard to medical services - for which solutions can be found in sectoral discussions. Sectoral considerations here are frequently not specific to developing countries. Secondly, care must be taken in sectoral negotiations to ensure that no unnecessary restrictions are imposed on the exchange of services under the guise of sector-specific requirements. ${ }^{23}$ Thirdly, in the interest of developing countries, the possibility of applying the "infant industry" argument must be guaranteed. ${ }^{24}$ While there is no systematic relation between the development of the service sector

20 Much less attention will thus be paid in the discussion which follows to points concerning the applicability of GATT to services in general.

${ }^{21}$ Legitımate consideratıons according to which protection takes the form of an emergency measure, e.g. for safeguard purposes or to deal with a balance of payments crisis, are passed over here.

22 An exemption from national treatment is in any case made under present GATT arrangements for the film sector, namely in Art. IV.

23 This is of particular concern to developing countries where their export position is at stake; see below.

24 In a recent article (Howard Pack, Larry E. Westphal: Industrial Strategy and Technological Change: Theory versus Reality, in: Journal of Development Economics, Vol. 22, 1986, pp. 87-128) the relevance of the "infant industry" argument to new industries in particular is demonstrated in the light of developments in Korea. 
in general and economic development, the fact remains that modern services in particular are fairly knowledgeintensive. Thus developing countries generally lag appreciably behind in this respect for, even more than in sectors making intensive use of physical capital, their comparative disadvantage lies in sectors intensive in the use of human capital.

Clearly it is in the nature of modern services that their development only gets under way at a later stage in the development process, after industrialization. In addition, consumer preference in the developing countries in particular acts to the disadvantage of new domestic service suppliers and to the advantage of foreign suppliers. The domestic service industry must therefore be given the chance of demonstrating the value of its own product. It should be noted in passing that it is essential for the government to create the institutional framework for this by the adoption of regulatory measures and the monitoring of rules. An appropriate recommendation would thus be to establish for services the principle that developing countries have no obligations in the matter of offering counterconcessions. Countries which, in accordance with certain objective standards, might qualify for graduation could be offered a transitional period on the basis of a limited "infant industry" argument.

In other words, protection of a service sector should decrease over time, where possible, and should be limited in time. This is not just to favour foreign competition, it also reduces the "once an infant, always an infant" risk. After such a transition period, the developing country in question would be subject to the same obligations as the industrialized countries.

\section{Restrictive Business Practices}

A second objection to national treatment stems from the fear of the developing countries that monopolistic tendencies will come into prominence in the service sector more than in the goods sector. ${ }^{25}$ In other words the foreign supplier is so much stronger and bigger than the domestic competition that he can effectively function as a monopoly, with all the detriment associated with

${ }^{25}$ It is very interesting to note that the European Commıssion also tends to take that position as a point of general, not just developing countries' concern; see J. Richardson: The European Community International Trade in Services and the Uruguay Round, paper delivered at the Conference on EC Trade Policy and the GATT Round, organized by the Interdisciplinary Studygroup on European Integration, The Hague, May 22, 1987.

\title{
PUBLICATIONS OF THE HWWA-INSTITUT FÜR WIRTSCHAFTSFORSCHUNG-HAMBURG
}

\author{
Armin Gutowski, Manfred Holthus, Dietrich Kebschull (eds.)
}

\section{INDEBTEDNESS AND GROWTH IN DEVELOPING COUNTRIES}

The debt crisis in the developing countries has reached alarming proportions. How can it be dealt with? How can critical aggravations be avolded in future? The HWWA-Institute has conducted research in this field for many years. This book contains articles most of which have been published in HWWA journals. They were written by experts who have been researching into this difficult subject for a long time.

Large octavo, 344 pages, 1986, price paperbound DM 49,-

ISBN 3878953003
V E R L A G
W E L T A R
C H I V
G M B H
H A M B U R G 
monopolies. This is also referred to as restrictive business practices. One way of obviating this situation is to admit several foreign competitors, which is a natural consequence of the most favoured nation principle. In many developing countries however the market may be too small to make this attractive. Here too there are legitimate reasons for allowing developing countries in particular to depart from the national treatment principle.

\section{The Role of Direct Foreign Investment}

A third objection on the part of the developing countries to the liberalization of trade in services also relates to the national treatment principle. In this case however it is not so much a question of the desire to be able to protect their own service industries as of the wish to distinguish between the treatment of the foreign supply of services and the treatment of foreign suppliers of services. As has been pointed out already trade in services, more that that in goods, goes hand in hand with direct foreign investment. The national treatment of foreign investors would make it impossible for developing countries to impose conditions on the establishment of foreign investors in order to maximize the profit they stand to gain from those investors. It also touches on politically sensitive areas, such as national sovereignty.

This objection calls for the following comments. Firstly it is hardly possible to require national treatment for investors in the service sector without doing the same for investors in the goods sector. National treatment would thus have to be required for investors in general. Secondly GATT is not a production agreement but a trade agreement. It therefore concerns trade in products, not the movement of production factors between countries. Thus not only does GATT not cover the migration of labour, it does not apply to the migration of capital and associated production factors either.

In the formulation of a code for services therefore, a clear distinction must be made between the supply of services and foreign investment. Liberalization must apply to the former, not the latter. Of course some latitude must be provided in respect of foreign investors in order to prevent restriction of investment leading to restriction of the supply of services from abroad. This would have to be regulated on a sector by sector basis in accordance with the different minimum requirements for domestic representation in each sector. The criterion here would have to be a sales unit rather than a production unit.

Following on from the desirability of offering developing countries in particular a certain latitude for promoting the development of their service industries, there is also the concern to maintain certain key areas of service provision in national, often state, hands. Of relevance here are certain infrastructure services in the field of telecommunications. This is crucial, bearing in mind that most other modern services sectors depend on the efficient operation of such services. The developing countries are no doubt not alone in this respect. ${ }^{26}$ It may accordingly be assumed that a certain measure of agreement will have to be reached on the identification of areas of the telecommunications industry which may need to be protected from foreign influence. Moreover this problem should also be approached on the basis of a careful distinction between the supply of services and foreign investment, with infrastructure provision remaining in the control of the national authorities.

\section{Intersectoral Retaliation}

There remains the fear of developing countries that bringing the service sector within the scope of GATT will open up the possibility of intersectoral retaliation in line with GATT practice.

This possibility currently exists in the trade legislation of the United States. It is to be recommended that ways should be sought, within the framework of the negotiations on services, of excluding this possibility where developing countries are concerned, i.e. to keep retaliation within the service sector. The sensitivity of a developing country to retaliation would then be the greater, the more export interests it had in this sector. Accordingly the pressure to open up their markets would also be greater. A consequence of this would be that, in the event of the graduation of a developing country, the possibility of intersectoral retaliation would of course reemerge, since the very fact of graduation means that a developing country takes on the same obligations as industrialized countries.

\section{The Export Side}

Although developing countries are net importers of services overall, there are sectors and countries in which this general picture does not apply. Moreover, changes can occur in modern services sectors, offering developing countries scope for profit, particularly those with a relatively well-educated population. Then there are developing countries which have distinct comparative advantages in construction, a labourintensive service sector.

It is important therefore, particularly with the future in

${ }^{26}$ For sımılar consıderations, see agaın J. RI chard s o n, op. sit. 
mind, to keep open as many options relevant to developing countries as possible. The first thing to establish is that the granting of tariff preferences in the service sector is not a very viable option because import tariffs are largely absent. That does not mean that other forms of special treatment for developing countries are not available. It might be possible, in the transport sector for example, to reserve a section of the market for the developing countries. ${ }^{27}$ Next the aim should be, as a minimum requirement but at the same time in full conformity with GATT rules, to apply the most favoured nation principle to the service sector as a general starting-point. ${ }^{28}$ In this case the definition of the service sector should be wide enough to include the construction industry. Although of course the problem of labour migration crops up here, the same considerations apply as those reviewed earlier in connection with foreign investment in developing countries. GATT is not concerned with international flows of production factors but, to the extent that the movement of production factors across frontiers - in this case labour on a semi-permanent basis - is necessary for the international supply of a service, it is of great importance to developing countries that this should be accommodated by means of GATT regulation.

Freedom in respect of trans-border data flows is also important to developing countries because of their interest in being able to supply "over-the-wire" services to the industrialized countries. Generally speaking it is important, finally, to ensure that the industrialized countries do not attempt, by spurious, sector-specific arguments, to impose restrictions on developing countries in sectors of relevance to them. As an example of such considerations one might think of the emphasis on workers' rights, minimum wages and working conditions in general in order to justify protecting the textile and garment sector within the framework of the MFA or limiting preferences under the GSP.

\section{Concluding Remarks and Policy Recommendations}

The start of the Uruguay Round constitutes a first step towards liberalization of international trade in services. The attitude of developing countries to this prospect in the run-up to the launching of the Uruguay round varied from strong opposition to a certain reluctance. Nevertheless they have agreed to the inclusion of services in the new round in the form of a two-track procedure, i.e. one track for goods and another for services. It must be emphasized that liberalization of trade in services will also involve aspects of foreign investment and migration of labour. Provision should be made for them to the extent that they are necessary for liberalizing trade in services, since otherwise the entire exercise serves no purpose as the liberalization of trade could be cancelled out by regulatory measures in the field of foreign investment and migration.

In order to ensure maximum involvement of developing countries in the negotiations it is necessary to give sufficient prominence in the negotiations to the problems anticipated and wishes indicated by them. The key consideration here is that liberalization of trade in services is a good thing for developing countries too, and that it should contribute as much as possible to their growth and development. In other words, in the case of services just as in that of goods, due consideration must be given to the special position of developing countries. This aim might be furthered in the following manner:

Developing countries must be free to give a certain measure of protection to their service industries on grounds of "infant industry" considerations.

It is necessary to examine to what extent developing countries should be free to depart from the principle of "national treatment" in respect of services on grounds of restrictive business practices and/or development objectives.

$\square$ Direct foreign investment should only be covered by liberalization to the extent that it is strictly necessary for supplying a service.

The possibility of intersectoral retaliation against developing countries should be restricted to a minimum, for example by allowing it only with respect to developing countries which objectively qualify for graduation.

Export industries of interest to developing countries in the service sector must also be covered by the negotiations.

The possibility of preferential treatment for developing countries should be examined. Where preferential treatment is possible, it should be applied.

$\square$ Industrialized countries must also open up their markets in areas outside the service sector, particularly in the tradtitional goods sectors, in which many developing countries have a comparative advantage, one that is still being undermined by all kinds of protective measures on the part of industrialized countries.

27 The developıng countries could be offered assistance outside the framework of GATT in establishing their service sectors, for example by stimulating the transfer of technology.

${ }^{28}$ Developing countries' export interests are also harmed when aid is tied to procurement in the donor country 